OPEN ACCESS

Approved by:

Frontiers Editorial Office,

Frontiers Media SA, Switzerland

${ }^{*}$ Correspondence:

A. Opitz-Welke

Annette.opitz-welke@charite.de

${ }^{t}$ These authors have contributed equally to this work

Specialty section:

This article was submitted to

Forensic Psychiatry,

a section of the journal

Frontiers in Psychiatry

Received: 01 December 2019

Accepted: 04 December 2019

Published: 17 January 2020

Citation:

Seidel P, Konrad N, Negatsch V,

Dezsö D, Kogan I, Gauger U,

Neumann $B$, Voulgaris $A$ and OpitzWelke A (2020) Corrigendum: Violent Behavior During Psychiatric Inpatient

Treatment in a German

Prison Hospital.

Front. Psychiatry 10:961

doi: 10.3389/fpsyt.2019.00961

\section{Corrigendum: Violent Behavior During Psychiatric Inpatient Treatment in a German Prison Hospital}

\author{
P. Seidel ${ }^{1}$, N. Konrad ${ }^{2}$, V. Negatsch ${ }^{2}$, D. Dezsö ${ }^{2}$, I. Kogan ${ }^{2}$, \\ U. Gauger ${ }^{2}$, B. Neumann ${ }^{2}$, A. Voulgaris $^{3 \dagger}$ and A. Opitz-Welke ${ }^{2 * t}$ \\ 1 Justizvollzugskrankenhaus, JVA Plötzensee, Berlin, Germany, ${ }^{2}$ Institut für Forensische Psychiatrie, Charité, Berlin, Germany, \\ 3 Institut für Sexualforschung und Forensische Psychiatrie, Universitätsklinikum Hamburg Eppendorf, Hamburg, Germany
}

Keywords: violent behavior, mental disorder, prison hospital, schizophrenia, age

\section{A Corrigendum on}

Violent Behavior During Psychiatric Inpatient Treatment in a German Prison Hospital by Seidel P, Konrad N, Negatsch V, Dezsö D, Kogan I, Gauger U, Neumann B, Voulgaris A and Opitz-Welke A (2019). Front. Psychiatry 10:762. doi: 10.3389/fpsyt.2019.00762

In the published article, there was an error in affiliation for "D. Dezsö" and "I. Kogan." Instead of "Justizvollzugskrankenhaus, JVA Plötzensee, Berlin, Germany," it should be "Institut für Forensische Psychiatrie, Charité, Berlin, Germany." The affiliations have been updated accordingly.

The authors apologize for this error and state that this does not change the scientific conclusions of the article in any way. The original article has been updated.

\footnotetext{
Copyright (c) 2020 Seidel, Konrad, Negatsch, Dezsö, Kogan, Gauger, Neumann, Voulgaris and Opitz-Welke. This is an openaccess article distributed under the terms of the Creative Commons Attribution License (CC BY). The use, distribution or reproduction in other forums is permitted, provided the original author(s) and the copyright owner(s) are credited and that the original publication in this journal is cited, in accordance with accepted academic practice. No use, distribution or reproduction is permitted which does not comply with these terms.
} 